\title{
Phenological Growth Stages of Saffron (Crocus sativus L.) under Temperate Conditions of Jammu \& Kashmir-India
}

\author{
Salwee Yasmin and F.A. Nehvi* \\ Sher-e-Kashmir University of Agricultural Sciences and Technology of Kashmir, Shalimar, \\ Srinagar-190021, India \\ *Corresponding author
}

\section{Keywords \\ Developmental stages, Weather, Morphological criteria, Phenology, \\ Saffron (Crocus sativus L.)}

Article Info

Accepted:

30 March 2018

Available Online:

10 April 2018

\section{A B S T R A C T}

Phenological studies at different stages of crop growth are important to mitigate the ill effects of climate change to which saffron is very much sensitive and to predict the production system modules involving cultural practices and crop protection systems. Study on phenological growth stages of natural temporal sub-populations of Kashmir saffron (Crocus sativus L.) carried over 2 years revealed that the ontogenesis period of saffron with above ground organs is almost similar to period showing no organs above ground. Among ontogenic periods vegetative phase is the longest period (142 days), followed by flower ontogenesis (60 days), dormancy (55 days), reproductive (41 days),bud sprouting phase (36 days) and plant senescence (30 days). Timing of the phenological stage is observed to be closely related to weather parameters particularly air temperatures. Dormant corms show reduced impression of mother corm. No change in the size of the bud (the length of the outermost cataphylls) was observed from the time of corm lifting in early May to late June, some 55 days after leaf senescence. Incubation period of 97 days lead to increase in size of the apex followed by the formation of sprouts with complete flower embedded in whorl of tepals (Gynoecium, stamen, tepals). Initial corm weight has been found responsible for increased number of flowers/spathe, more activation of meristematic regions and greater biomass leading to efficient replacement corm production. The flowering stage starts when the sprout (usually composed of three sheaths) emerges from the soil surface and is influenced by weather parameters. Vegetative stage is most critical as chilling requirement for vernalization is received during 66 days $\left(11^{\text {th }}\right.$ November to $15^{\text {th }}$ February). The period is critical for development of replacement corms which largely depends on efficient translocation of photosynthates from source to sink. Phenological growth stage is completed with plant senescence with production of full mature corms showing impression of mother corms. A staging system for development saffron (Crocus sativus L.) that relies on simple, visual, non-destructive criteria was proposed to allow for quick determination of development stage. This system can be used by both farmers and for experimental trials.

\section{Introduction}

India has a distinction of being second largest producer of saffron globally after Iran. Most expensive spice appreciated because of its colouring, flavouring and aroma capacity is being called "the red gold" (Poggi, 2009). Saffron produced in India is worldwide known 
for its best quality and is recognized to be produced in the state of Jammu and Kashmir (Salwee et al., 2012). Seasonal weather changes are significant in the saffron growing areas areas and saffron plants have been able to develop survival mechanisms coping with adverse conditions derived from higher or lower temperatures as well as extreme drought events (Wareing and Phillips, 1981; Pérez Bueno, 1988).

Vela et al., (2013) laid emphasis on the characterization of the phenological stages for saffron crop production as cultural practices depends largely on importance of certain critical stages of crop growth (Vela et al., 2013).Many reports are available on morphology and annual cycle of saffron plant (Chrun-goo et al., 1983; Botella et al., 2002; Carmona et al., 2006; Poggi, 2009). Nevertheless, there are currently no universally used keys to describe the entire development cycle of this plant.

The study of identifiable changes that occur during the course of plant development occurring due to cell differentiation and organ initiation and are influenced by environmental factors is defined as plant phenology (Hodges, 1991, Meier et al., 2009a). Time interval different stages of morphogenesis (developmental stage) of an organ, is defined as a developmental phase (Streck et al., 2003). An organ can be identified using magnification (hand lens or microscope) or in some cases by the naked eye. Understanding of developmental events including developmental phase, a code (a number, a set of letters or a combination of letters and numbers) and a description (criteria) of each developmental stage followed by their sequencing is an important tool to standardise communication with all those concerned with crop production directly or indirectly (Zadoks et al., 1974; Fehr and Caviness, 1977; Counce et al., 2000).
For several agricultural crops developmental scale has been put forth viz., soybean (Fehr and Caviness, 1977), maize (Hanway, 1966; Ritchie et al., 1993), wheat (Large, 1954; Zadoks et al., 1974) and rice (Counce et al., 2000), and fruit crops such as persimmon tree (Garcia-Carbonell et al., 2002), olive tree (Sánz-Cortés et al., 2002), coffee tree (Morais et al., 2008) and mango tree (Delgado et al., 2011). Some floral crops also have phenological scale such as Rosa sp. (Meier et al., 2009b), Zinnia elegans (Gonçalves et al., 2008), Saffron (Horacio Lopez-Corcoles et al., 2015) and Gladiolus (Schwab et al., 2015). A world-wide Coding system commonly used to integrate phenological studies is based on extended BBCH-scale proposed by Hack et al., (1992). Staging system of Schwab et al., (2015) is easier for end users such as extension agents and growers than a system coded only with numbers such as the Zadoks' scale (Zadoks et al., 1974) and the BBCH system (Meier et al., 2009a). Sher-e-Kashmir University of Agricultural Sciences and Technology of Kashmir is premier University in India doing research on saffron. Based on this background, the objective of this present investigation was to create a staging system for describing the development of saffron that relies on simple, visual and non-destructive criteria that are easy-to-use.

\section{Materials and Methods}

The experimental site has been famous abinitio by its original name Padampore situated along the banks of river Vatista, which flows down to North-Southward bank-the direction in which the prominent historical places such as Lethpora, Chandhara, Konibal, Dussu, Ladhoo, Shar, Khrew, Wuyan and Balhama are inhabited. Pampore is located at $34^{\circ} 01 \mathrm{~N}$ and $74^{\circ} 56^{\prime} \mathrm{E}$ with an average elevation of 1574 meters, about $25 \mathrm{~km}$ south-east of Srinagar in Kashmir. Studies were carried out on the temporal sub population of Saffron 
available at Saffron Research Station a constituent Research Station of SKUASTKashmir during 2015-16 and 2016-17.

Corms of different weight $(>10 \mathrm{~g}, 8-10 \mathrm{~g},<8 \mathrm{~g})$ were uprooted at 15 days interval timing and after removal of protective cataphylls, the shoot apex was examined under trinocular microscope. A further characterization of flower initiation was performed viewing longitudinal sections through the central part of the apex and naked shoot apex was observed after removal of protecting sheath of cataphylls.

A plant development system needs four main features (Counce et al., 2000): (a) dichotomous criteria based on plant morphogenesis (i.e. discrete morphological criteria which are either present or absent) to identify developmental stages and phases; (b) a basis on actual events rather than indications; (c) a wide range of geographical application and (d) visible criteria or markers readily identifiable with a small hand lens (about 10× magnification).

Following the approaches provided by Horacio Lopez-Corcoles (2015) and Schwab et al., (2015) Saffron morphogenesis was divided into six stages: corm dormancy, flower ontogenesis, bud sprouting, reproductive, vegetative and plant senescence. Studies were carried out on ten plants that were randomly sampled when they reached each developmental stage. Package of practices to raise a good crop were followed as per recommendations of SKUAST-Kashmir (Nehvi et al., 2011, 2017). To study impact of weather parameters on saffron morphogenesis meteorological data was recorded from MET observatory Saffron Research Station Pampore. Based on this background, the present investigation was carried to describe the phenological growth and developmental stages of saffron plant.

\section{Results and Discussion}

The ontogenesis of Kashmir saffron (Crocus sativus L.) spread over 6 developmental stages from $1^{\text {st }}$ May to 25th June (corm dormancy), $26^{\text {th }}$ June to $25^{\text {th }}$ August (flower ontogenesis), $26^{\text {th }}$ August to $20^{\text {th }}$ October (bud sprouting), $1^{\text {st }}$ October to $10^{\text {th }}$ November (Reproductive), $11^{\text {th }}$ November to $30^{\text {th }}$ March (Vegetative) and $1^{\text {st }}$ April to $30^{\text {th }}$ April (Plant senescence) under temperate conditions of Kashmir is presented in Table 1. The ontogenesis period of saffron with above ground organs (183 days). is almost similar to period showing non above ground organs (182 days). However, Molina et al., (2005) reported longer period of saffron without above ground organs. Study revealed that among various ontogenic periods vegetative phase is the longest period (142 days), followed by flower ontogenesis (60 days), dormancy phase (55 days), reproductive (41 days), bud sprouting phase (36 days) and plant senescence (30 days). Timing of the phenological stage is observed to be closely related to weather parameters particularly air temperatures (Minimum and Maximum). Relative Humidity on an average was observed to be uniform over different timings of phenological stages. The earlier rise in temperature from $26.1^{\circ} \mathrm{C}$ (dormancy) to $29.3^{\circ} \mathrm{C}$ (flower ontogenesis) during summer (26 $6^{\text {th }}$ June to $26^{\text {th }}$ August) accelerates flower initiation. Average air temperature of $27.5^{\circ} \mathrm{C}$ with a total precipitation of $418.90 \mathrm{~mm} / \mathrm{ha}$ (33.70\% of total precipitation) favoured shoot and root development. When the average maximum air temperature reaches below $20.0^{\circ} \mathrm{C}$ anthesis is favoured under temperate conditions of Kashmir. Similar findings of importance of mean air temperature of $15.0^{\circ} \mathrm{C}$ to $17.0^{\circ} \mathrm{C}$ for anthesis in saffron have also been reported by Molina et al., (2015). A low average temperature of $11.4^{\circ} \mathrm{C}$ accompanied with sub-zero temperatures $\left(-0.33^{\circ} \mathrm{C}\right)$ ensures development of replacement corms through better photosynthetic accumulation resulting 
in efficient source sink relationship (Figure 1, Table 2).

\section{Dormancy phase}

Corm is a sub soil organ, composed mainly of parenchymatous tissue which stores substances needed for flowering and sprouting. On an average, corms vary in size from 1.5 to $3.9 \mathrm{~cm}$ in diameter and $1 \mathrm{gm}$ to $>$ $20 \mathrm{gm}$ in weight and are tunicated with varying shapes from flattened to ovoid or subglobose. The sheath which represents the expanded base of the sheathing leaves (scales) surrounds the corm. The tunic has fine reticulate, or parallel fibers extended upwards around $5 \mathrm{~cm}$ above the neck of the plant. Apical, subapical and auxillary buds are observed in internodes and are also seen protected by dark reddish scales. $80 \%$ of all the buds are located in the upper central part of the corm and can be classified into two groups: buds of a mixed nature that develop vegetative- reproductive sprouts, that is, which can produce leaves and flowers (Apical and sub-apical buds) and leaf producing or axillary buds. As the diameter of the corm increases, the buds tend to group together, so that, majority can be found in one, two or three internodes (Salwee and Nehvi, 2014). Because of the flowering in apical sprout, a depression is found in the central apical area of the corm where floral remains are observed. Average number of sprouts range from 1 to 11 with average number of reproductive sprouts ranging from 0 to 3 . During dormancy (Stage 0) saffron corms apparently show neither morphological change nor external growth and the apex looks like a resting bud with protective cataphylls (Figure 2). However, Le Nard and De Hertogh (1993) reported that there do exist internal physiological and morphogenetic changes during dormancy period. Dormant corms show reduced impression of mother corm. No change in the size of the bud (the length of the outermost cataphylls; flower score SO, Figure 1d) was observed from the time of corm lifting in early May to late June, some 55 days after leaf senescence. During this time, the buds made no growth and seemed to be dormant. No flower initials were present in the resting buds). Similar phenology for corm dormancy in gladiolus has also been reported by Schwab et al., (2015). During dormancy saffron corms receive about $28 \%$ of total annual precipitation $(347.85 \mathrm{~mm})$ accompanied with high relative humidity. Wet weather conditions predispose corms to the infection of Fusarium species and Rhizoctonia solini if management practices are not followed in time. Saffron fields are subjected to first hoeing during dormancy period prior to $25^{\text {th }}$ June to facilitate aeration of soil. But leaving the soil with wide air spaces triggers the rot infections due to increased soil temperature and humidity and therefore proper soil dressing immediately after first hoeing is advocated to save corms from damage (Nehvi et al., 2017).

\section{Flower ontogenesis}

Flower ontogenesis was studied from $26^{\text {th }}$ June to $25^{\text {th }}$ August as also reported by Molina et al., (2004). The numerical scale used for flower differentiation was based on the stages of meristem development as defined by Beyer (1942). The main stages are illustrated in Table 1 and Figure 3. Incubation period of 61 days $\left(26^{\text {th }}\right.$ June to $25^{\text {th }}$ August) at an average day and night temperature of $29.39^{\circ} \mathrm{C}$ and $16.5^{\circ} \mathrm{C}$, morning and evening relative humidity of $82.9 \%$ and $55.5 \%$ associated with a total precipitation of $294.5 \mathrm{~mm}$ lead to increase in size of the apex followed by the formation of leaf primordia (flower score, F0.1; Figure 3a). Shortly afterwards the sheathing leaves started to grow at a faster rate than the shoot apex and protecting the growth of the young shoot and the scape. In succession the formation of stamen primordia (flower score, FO.2; Figure 3b), leaf primordia development is at the base of meristem (flower 
score FO.3; Figure 3c) and the formation of gynoecium (flower score, FO.4; Figure 3d) were observed. The stamens were observed to be much longer than the leaves, a consequence of the hysteranthy of this species. All the flower parts were already differentiated by the end of August. Results are in confirmation with the studies of Molina et al., (2004) carried under filed conditions of Albacete Spain but contradict for number of days taken and incubation temperature elapsed from the initiation of the leaves to the initiation of gynoecium. Koul and Farooq (1984) reported that although important flower ontogenic process leading to differentiation of floral and vegetative buds take place, nothing is observed externally. During this period, growers prepare the corms for fresh plantation after digging followed by sorting and cleaning to rejuvenate their saffron crop.

\section{Bud sprouting}

Flower ontogenesis is followed by bud sprouting (Table 1, Figure 4, 5 and 6). There are four stages within the sprouting phase: BS (Figure 4a, 4d and 4g), BS.1 (Figure 4b, 4e and 4h), BS.2 (Figure 4c) and BS.3 (Figure $4 \mathrm{f}$ and 4i). Under temperate conditions of Kashmir all the developmental stages of the sprouting phase occur beneath the soil between $26^{\text {th }}$ August to $30^{\text {th }}$ September (36 days) under average maximum air temperature of $27.5^{\circ} \mathrm{C}$, minimum air temperature of $11.25^{\circ} \mathrm{C}$, morning relative humidity of $84 \%$, evening relative humidity of $52.6 \%$ and precipitation of $92.25 \mathrm{~mm}$ (Figure 1 and Table 2). Sprout initiation from the apical and axillary buds accompanied with fibrous root formation from the corm disc has been observed to be related to initial corm weight. Corms weighing $>8 \mathrm{~g}$ attain a length of $13 \mathrm{~cm}$ during the sprout incubation period of 36 days $\left(26^{\text {th }}\right.$ August to $30^{\text {th }}$ September) whereas, corms weighing $<8 \mathrm{~g}$ attain a length of $4.6 \mathrm{~cm}$ during this period thus would result in delayed initiation of above ground organs. Study on uprooted corms revealed that corms weighing $>10 \mathrm{~g}$ attains a length of $4 \mathrm{~cm}$ in 15 days $\left(9^{\text {th }}\right.$ September) which further increases to $12 \mathrm{~cm}$ $\left(19^{\text {th }}\right.$ September) and finally reaches to $13 \mathrm{~cm}$ by $30^{\text {th }}$ September (Figure 5). Sprouts with an average length of $4 \mathrm{~cm}$ recorded fully developed floral parts (Gynoecium, stamens, flower score, BS.1: (Figure $4 \mathrm{e}$ and $4 \mathrm{~h}$ ) and at $13 \mathrm{~cm}$ length sprouts recorded complete flower embedded in whorl of tepals (Gynoecium, stamen, tepals, flower score, BS.3: Figure $4 \mathrm{f}$ and $4 \mathrm{i})$. Initial corm weight is an indicator of number of floral primordial per spathe (Figure 6). Corms weighing $<8 \mathrm{~g}$ usually develop single sprout which lack any floral primordial due to reduced spathe width of $1.2 \mathrm{~cm}$. (Figure 7cand 7f), 4whereas corms weighing $>10 \mathrm{~g}$ recorded multiple sprouting associated with 3 flowers/spathe with maximum sprout width of $2.7 \mathrm{~cm}$ (Figure $7 \mathrm{a}$ and $7 \mathrm{~d}$ ). Corms weighing $8-10 \mathrm{~g}$ recorded sprout width of $1.7 \mathrm{~cm}$ revealing 1 flower/spathe (Figure $7 \mathrm{~b}$ and 7e). Study confirmed that increase in sprout width by 41$58 \%$ which is directly associated with initial corm weight results in proportionate increase in number of flowers/spathe by $200 \%$. Differences in corm size or seasonal variations have been considered the cause of these differences in transition dates (Negbi, 1999). Flower formation is directly related to corm size (Negbi et al., 1989; De Mastro and Ruta, 1993) and a quantitative relationship between these two parameters was found (Negbi et al., 1989). However, the role of ambient temperatures on flower bud differentiation and subsequent flowering is largely unknown. Plessner et al., (1989) reported the formation of a similar number of flowers in corms forced either under uncontrolled conditions (at around $15^{\circ} \mathrm{C}$ ) or in a phytotron at a $17 / 12^{\circ} \mathrm{C}$ (day/night) cycle.

\section{Reproductive}

Despite its importance, the flowering process in saffron has not been characterised precisely. 
The life cycle of saffron is similar in all producing countries, but there are wide differences in the timing of events (Botella et al., 2002). Flowering occurs during autumn (October-November). During the month of October, sprouts are visible above the ground and the sub-soil stem is short. Very fine roots also start to protrude in the form of crown from the third basal internodes, possibly reaching a length of $5 \mathrm{~cm}$. The flowering stage starts when the sprout (usually composed of three sheaths) emerges from the soil surface. Developmental stages are denoted as $\mathrm{R}$ stages (Figure 8). Flowering (sprout are visible above ground and saffron flower are within the sheath. Flower score R.1; Figure 8a), blooming (unopened flowers with floral organs enclosed by the tepals. Flower Score R.2; Figure 8 b), anthesis (opened tepals with visible stigma and anthers. Flower Score R.3; Figure 8c) and flower senescence (when the tepals dehydrate and falls on the ground. Flower ScoreR.4; Figure 8d) are major developmental stages (Table 1).

Saffron flowering (emergence of sprouts above ground) is controlled by air temperature. Study confirmed that maximum air temperature of $17.5^{\circ} \mathrm{C}$ accompanied with minimum air temperature of $1.8^{\circ} \mathrm{C}$, morning relative humidity of $86.1 \%$ and evening relative humidity of $65.5 \%$ was ideal for saffron flowering under temperate conditions of Kashmir (Figure 1 and Table 2). Above $20^{\circ} \mathrm{C}$ maximum day temperature recorded from $1^{\text {st }}$ October to $20^{\text {th }}$ October inhibited saffron flowering thereby indicating influence of temperature on saffron flowering. However results of reduction in flowering outside the range of $23-27^{\circ} \mathrm{C}$ has been reported by Molina et al., (2005). Saffron flowering followed by blooming and anthesis generally starts in the second fortnight of October and lasts up to the first week of November. Flowers emerge in 34 flushes with massive emission known as covering in the $2^{\text {nd }}$ flush. Each flush lasts for 2-6 days. Similar reports have been suggested by Dhar and Mir, (1997) and Nehvi et al., (2017). Anthesis phase lasts for 4-6 days after which the saffron flowers record flower senescence. Un-opened flower buds are visible 2-3 days after flowering (Sprout initiation). The purple saffron flowers have three violet sepals and three petals together called tepal. At the bottom, they are joined in the perianth tube. Tepals are violet in color with darker vein. Flowers are erect. The perianth tube serves as a stem between the ovary and the flower. Perianth segments are almost equal, 3$6 \mathrm{~cm}$ in length and 1-2.5 cm wide, oblanceolate to ovate. The flower has an underground ovary, a style (5 to $9 \mathrm{~cm}$ long), dividing at the top into three red trumpet like stigmas (2 to $3 \mathrm{~cm}$ long) which when dried form the commercial spice- the saffron The flowers of Crocus are bisexual. Pistil is central with a tubular ovary with a style. The style is long and pale yellow that is branched to an orange red three-branch stigma. Androecium consists of three distinct stamens three in number and smaller than perianth. Anthers are on top of the filaments. There are three stamens joined to the outer perianth segments but are smaller than perianth. The length of the filament is $10 \mathrm{~mm}$ and that of the anthers 15 to $20 \mathrm{~mm}$. The anthers are yellow in color and the filament white in colour. However in the apparent groove of the pedicel, the filaments are slightly pigmented and appear light purplish (Salwee et al., 2017). Structural variations for tepal number, tepal shape, tepal colour, flower weight, Stamen number, Pistil length, stigma number and stigma shape are visible immediately after anthesis (opening of flower) and are valued if variations are heritable. Tepals followed by pistil and stamens contribute most to the mass of flowers with an average weight of $326 \mathrm{mg}$. Once the pistil is separated from the flowers, large quantities of bioresidues composed of tepals and stamens is obtained (301 $\mathrm{mg}$ ) accounting for $92.14 \%$ of the total flower weight. 
Table.1 The developmental staging system of saffron

\begin{tabular}{|c|c|c|c|c|}
\hline Stage & Period & Phase & Code & Description \\
\hline 0 & $\mathrm{I}^{\text {st }}$ May to $25^{\text {th }}$ June & Dormancy & SO & $\begin{array}{l}\text { saffron corms apparently show neither morphological } \\
\text { change nor external growth and the apex looks like a } \\
\text { resting bud with protective cataphylls }\end{array}$ \\
\hline \multirow[t]{5}{*}{1} & $\begin{array}{l}26^{\text {th }} \text { June to } 25^{\text {th }} \\
\text { August }\end{array}$ & $\begin{array}{l}\text { Flower } \\
\text { ontogenesis }\end{array}$ & FO & \\
\hline & $26^{\text {th }}$ June to $14^{\text {th }}$ July & & F0.1 & $\begin{array}{l}\text { Shoot apex has increased in size and leaves } \\
\text { differentiated at the flank }\end{array}$ \\
\hline & $15^{\text {th }}$ July to $25^{\text {th }}$ July & & F0.2 & Stamen initiate \\
\hline & $\begin{array}{l}26^{\text {th }} \text { July to } 15^{\text {th }} \\
\text { August }\end{array}$ & & F0.3 & $\begin{array}{l}\text { Base of meristem covered by the developing leaf } \\
\text { primordia }\end{array}$ \\
\hline & $\begin{array}{l}16^{\text {th }} \text { August to } 25^{\text {th }} \\
\text { August }\end{array}$ & & F0.4 & Gynoecium formation \\
\hline \multirow[t]{4}{*}{2} & $\begin{array}{l}26^{\text {th }} \text { August to } 30^{\text {th }} \\
\text { September }\end{array}$ & Bud Sprouting & $\mathrm{BS}$ & $\begin{array}{l}\text { Sprout Initiation and fibrous root development and } \\
\text { Longitudinal section showing floral initials in } \\
\text { vascular bundle }\end{array}$ \\
\hline & $\begin{array}{l}26^{\text {th }} \text { August to } 9^{\text {th }} \\
\text { September }\end{array}$ & & BS.1 & $\begin{array}{l}\text { Sprout length reaches to } 4 \mathrm{~cm} \text { length and } \\
\text { Longitudinal section showing floral parts in the } \\
\text { sprout }\end{array}$ \\
\hline & $\begin{array}{l}10^{\text {th }} \text { September to } \\
19^{\text {th }} \text { September }\end{array}$ & & BS.2 & $\begin{array}{l}\text { Sprout length reaches to } 12 \mathrm{~cm} \text { and Longitudinal } \\
\text { section showing floral parts in the sprout }\end{array}$ \\
\hline & $\begin{array}{l}20^{\text {th }} \text { September to } \\
30^{\text {th }} \text { September }\end{array}$ & & BS.3 & $\begin{array}{l}\text { Sprout length reaches to } 13 \mathrm{~cm} \text { and Sprout showing } \\
\text { complete floral parts embedded in whorl of tepals }\end{array}$ \\
\hline \multirow[t]{5}{*}{3} & $\begin{array}{l}1^{\text {st }} \text { October to } 10^{\text {th }} \\
\text { November }\end{array}$ & Reproductive & $\mathrm{R}$ & $\begin{array}{l}\text { sprout are visible above ground and saffron flower } \\
\text { are within the sheath }\end{array}$ \\
\hline & $\begin{array}{l}1^{\text {st }} \text { October to } 10^{\text {th }} \\
\text { November }\end{array}$ & Flowering & R.1 & $\begin{array}{l}\text { Unopened flowers with floral organs enclosed by the } \\
\text { tepals }\end{array}$ \\
\hline & $\begin{array}{l}1^{\text {st }} \text { October to } 10^{\text {th }} \\
\text { November }\end{array}$ & Blooming & R.2 & opened tepals with visible stigma and anthers \\
\hline & $\begin{array}{l}1^{\text {st }} \text { October to } 10^{\text {th }} \\
\text { November }\end{array}$ & Anthesis & R.3 & opened tepals with visible stigma and anthers \\
\hline & $\begin{array}{l}1^{\text {st }} \text { October to } 10^{\text {th }} \\
\text { November }\end{array}$ & $\begin{array}{l}\text { Flower } \\
\text { Senescence }\end{array}$ & R.4 & When the tepals dehydrate and falls on the ground \\
\hline \multirow[t]{8}{*}{4} & $\begin{array}{l}11^{\text {th }} \text { November to } 3 \mathrm{o}^{\text {th }} \\
\text { April }\end{array}$ & Vegetative & VE & \\
\hline & $\begin{array}{l}11^{\text {th }} \text { November to } 31^{\text {st }} \\
\text { December }\end{array}$ & & VE.1 & $\begin{array}{l}\text { Leaves from the apicular bud region are first visible } \\
\text { above ground and leave grow at } 20 \% \text { of final length }\end{array}$ \\
\hline & & & VE.1 & $\begin{array}{l}\text { Leaves from the lateral bud region are first visible } \\
\text { above ground and leaves grow at } 10 \% \text { of final length }\end{array}$ \\
\hline & & & VE.1.1 & Leaves grow at $80 \%$ of final length \\
\hline & $\begin{array}{l}\text { I }^{\text {st }} \text { January to } 15^{\text {th }} \\
\text { February }\end{array}$ & & VE.2 & $\begin{array}{l}\text { Development of corm, lateral bud and terminal bud } \\
\text { contractile roots }\end{array}$ \\
\hline & $\begin{array}{l}16^{\text {th }} \text { February to } 30^{\text {th }} \\
\text { March }\end{array}$ & & VE.3 & Formation of replacement corms \\
\hline & & & VE.3.1 & Leaves grow at $100 \%$ of final length \\
\hline & & & VE.4 & Leaf and corm development completed \\
\hline \multirow[t]{2}{*}{5} & Ist April to $30^{\text {th }}$ April & & VE.5 & Leaves show signs of prominent senescence \\
\hline & & & VE 5.1 & Development of fully mature daughter corms \\
\hline
\end{tabular}


Table.2 Weather parameters under temperate conditions of Kashmir studied over different phenological stage

\begin{tabular}{|c|c|c|c|c|c|c|c|c|c|c|c|c|c|c|c|}
\hline Phenologicl Stage & Max & $\operatorname{emp}\left(^{\circ}\right.$ & & Min T & $\operatorname{emp}\left(^{\circ}\right.$ & & & RH 1( & & & RH 2 ( & $\%)$ & Preci & ation ( & nm) \\
\hline & $\begin{array}{l}2015 \\
-16\end{array}$ & $\begin{array}{l}2016 \\
-17\end{array}$ & Average & $\begin{array}{l}2015 \\
-16\end{array}$ & $\begin{array}{l}2016 \\
-17\end{array}$ & Average & $\begin{array}{l}2015 \\
-16\end{array}$ & $\begin{array}{l}2016 \\
-17\end{array}$ & Average & $\begin{array}{l}2015 \\
-16\end{array}$ & $\begin{array}{l}2016 \\
-17\end{array}$ & Average & $\begin{array}{l}2015- \\
16\end{array}$ & $\begin{array}{l}2016- \\
17\end{array}$ & Total \\
\hline $\begin{array}{l}\text { 1st May to 25th } \\
\text { June }\end{array}$ & 24.3 & 27.9 & 26.1 & 10.2 & 11.5 & 10.8 & 77.6 & 76.5 & 77.0 & 58.8 & 49.4 & 54.1 & 189.6 & 67.8 & 128.7 \\
\hline $\begin{array}{l}\text { 26th June to 14th } \\
\text { July }\end{array}$ & 27.8 & 31.7 & 29.7 & 16 & 16.5 & 16.2 & 78.9 & 75.6 & 77.2 & 60 & 47.5 & 53.7 & 76.7 & 11.6 & 44.15 \\
\hline $\begin{array}{l}\text { 15th July to 25th } \\
\text { July }\end{array}$ & 29.2 & 30.1 & 29.6 & 18.1 & 16.6 & 17.3 & 87.5 & 81.4 & 84.4 & 67.2 & 48.9 & 58.0 & 114.5 & 34.6 & 74.55 \\
\hline $\begin{array}{l}\text { 26th July to 5th } \\
\text { August }\end{array}$ & 29.5 & 28.8 & 29.1 & 18.2 & 16.8 & 17.5 & 87.1 & 87 & 87.0 & 60.1 & 56.8 & 58.4 & 169.4 & 62.8 & 116.1 \\
\hline $\begin{array}{l}\text { 6th August to 15th } \\
\text { August }\end{array}$ & 30.7 & 26.6 & 28.6 & 17.8 & 16.6 & 17.2 & 83.3 & 85.5 & 84.4 & 58.3 & 53.4 & 55.8 & 0 & 30.8 & 15.4 \\
\hline $\begin{array}{l}\text { 16th August to } \\
\text { 25th August }\end{array}$ & 29.9 & 29.4 & 29.6 & 15.2 & 14.1 & 14.6 & 79.4 & 84.3 & 81.8 & 50.4 & 52.9 & 51.6 & 82.8 & 5.8 & 44.3 \\
\hline $\begin{array}{l}\text { 26th August to 9th } \\
\text { September }\end{array}$ & 27.6 & 26.2 & 26.9 & 11.9 & 13.4 & 12.6 & 83.4 & 85.2 & 84.3 & 50.8 & 64.3 & 57.5 & 4.6 & 69 & 36.8 \\
\hline $\begin{array}{l}\text { 10th September to } \\
\text { 30th September }\end{array}$ & 26.2 & 29.0 & 27.6 & 9.5 & 10.4 & 9.9 & 80.2 & 87.3 & 83.7 & 52.9 & 42.8 & 47.8 & 61.8 & 3.1 & 32.45 \\
\hline $\begin{array}{l}\text { 1st October to } \\
\text { 20th October }\end{array}$ & 23.5 & 26.2 & 24.8 & 7.1 & 5.1 & 6.1 & 89.1 & 82.4 & 85.7 & 56.4 & 36 & 46.2 & 54.1 & 6.7 & 30.4 \\
\hline $\begin{array}{l}\text { 21st October to } \\
\text { 10th November }\end{array}$ & 14.8 & 21.1 & 17.9 & 3.9 & -0.3 & 1.8 & 87.4 & 84.9 & 86.1 & 68.8 & 62.2 & 65.5 & 3.5 & 0 & 1.75 \\
\hline $\begin{array}{l}\text { 11th November to } \\
\text { 31st December }\end{array}$ & 10.9 & 12.3 & 11.6 & -1.1 & -3.0 & -2.0 & 88.9 & 92.4 & 90.6 & 68.5 & 53.1 & 60.8 & 27.4 & 4.0 & 15.7 \\
\hline $\begin{array}{l}\text { 1st January to } \\
\text { 15th February }\end{array}$ & 10.3 & 5.7 & 8 & -2.1 & -1.9 & -2 & 91.8 & 91.5 & 91.6 & 59.3 & 72.7 & 66 & 56.8 & 438.4 & 247.6 \\
\hline $\begin{array}{l}\text { 16th February to } \\
\text { 30th March }\end{array}$ & 15.6 & 14 & 14.8 & 1.6 & 4.4 & 3 & 86.1 & 81.2 & 83.6 & 53.6 & 55.2 & 54.4 & 224.9 & 197.9 & 211.4 \\
\hline $\begin{array}{l}\text { 1st April to 30th } \\
\text { April }\end{array}$ & 18.7 & 19.9 & 19.3 & 6 & 6.5 & 6.2 & 87.6 & 81.9 & 84.7 & 68.9 & 58.1 & 63.5 & 116.8 & 321.5 & 219.15 \\
\hline
\end{tabular}


Fig.1 Ontogenesis of Kashmir Saffron viz-a-viz weather parameters averaged over two years

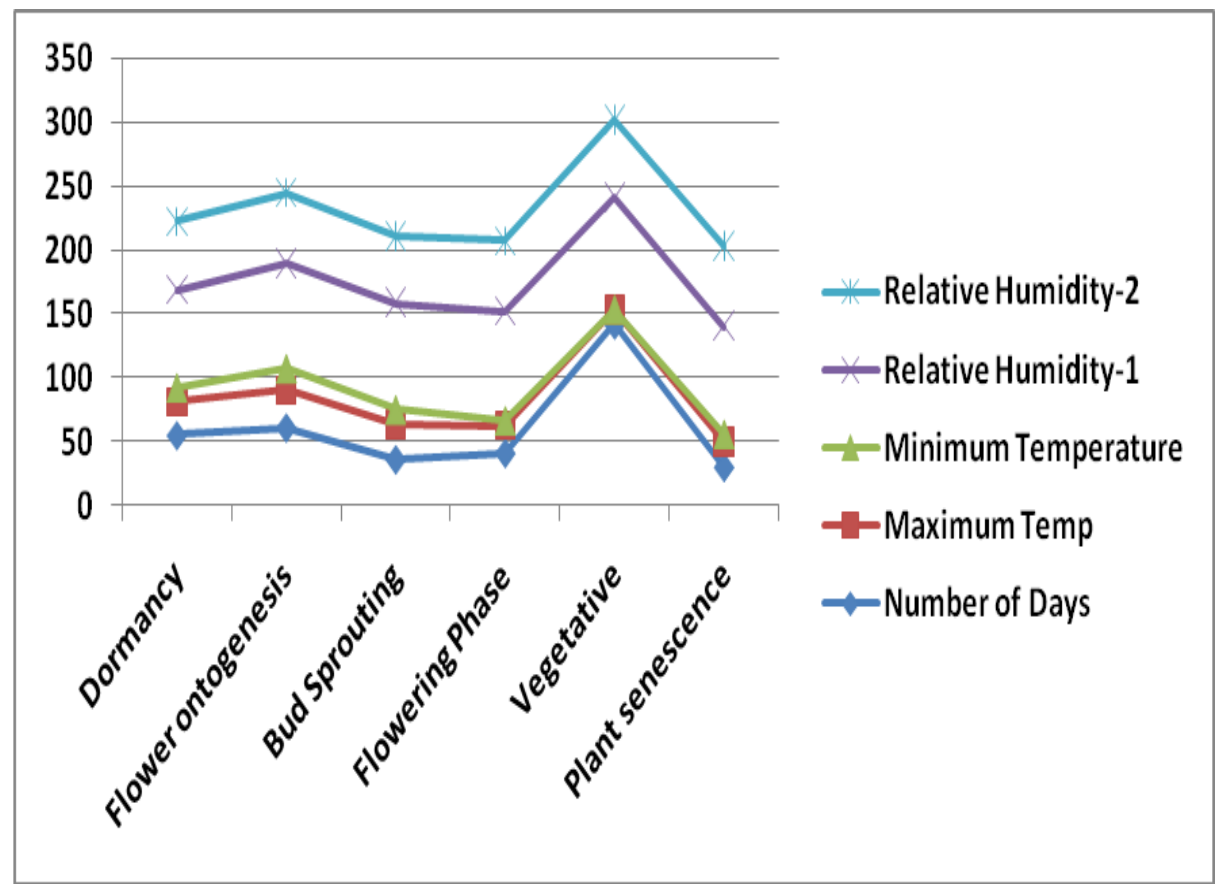

Figure 1

Fig.2 Corm Dormancy Phase (S0). a) Dormant corms with tunic. b) Dormant corm with mother corm residue. c) Naked corm showing dormant meristimatic regions. e) The apex of dormant corm looks like a resting bud with protective cataphylls

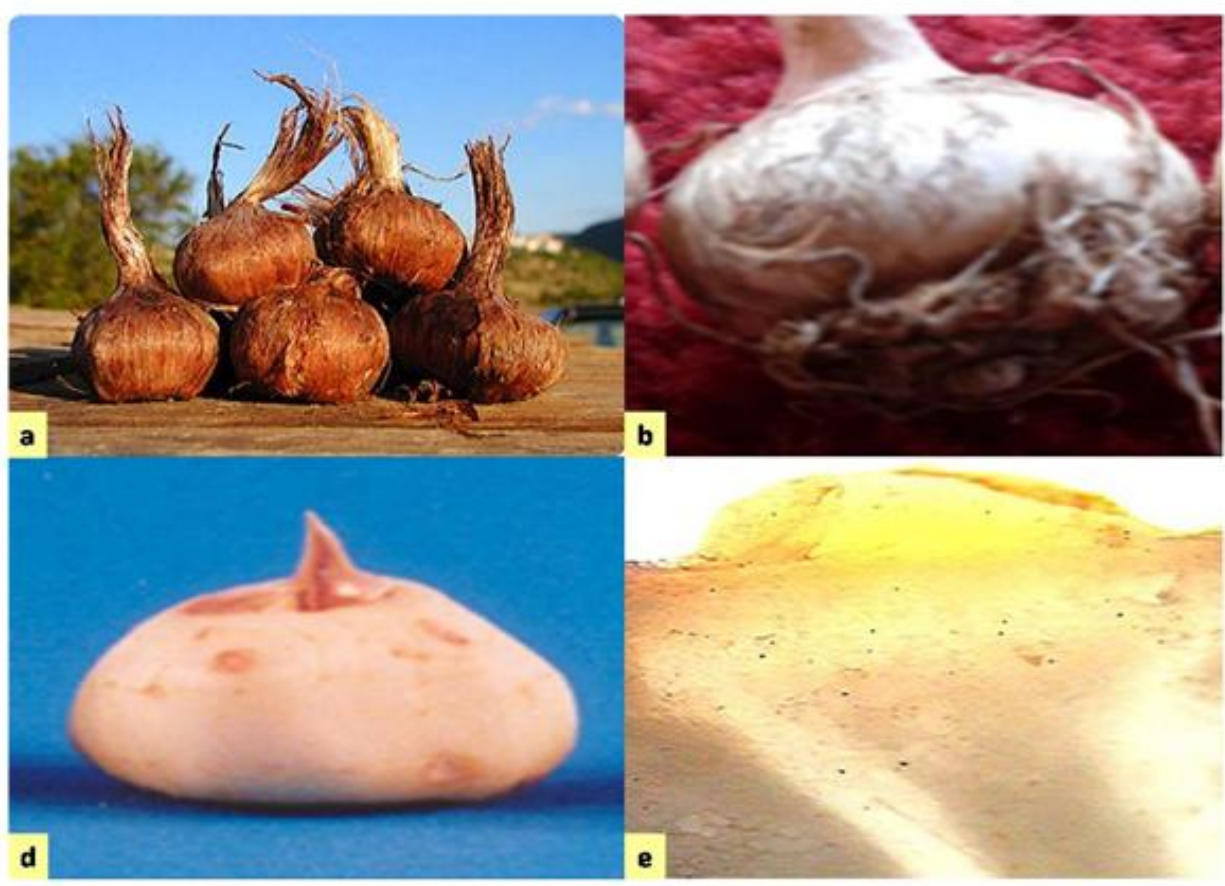

Figure 2 
Fig.3 Flower Ontogenesis Phase (FO). a) Shoot apex has increased in size and leaves differentiated at the flank (FO.1). b) Stamen initiate (FO.2). c) Base of meristem covered by the developing leaf primordia. The stamens are much longer than the leaves, a consequence of the hysteranthy of this species (FO.3). e) Gynoecium formation (FO.4)

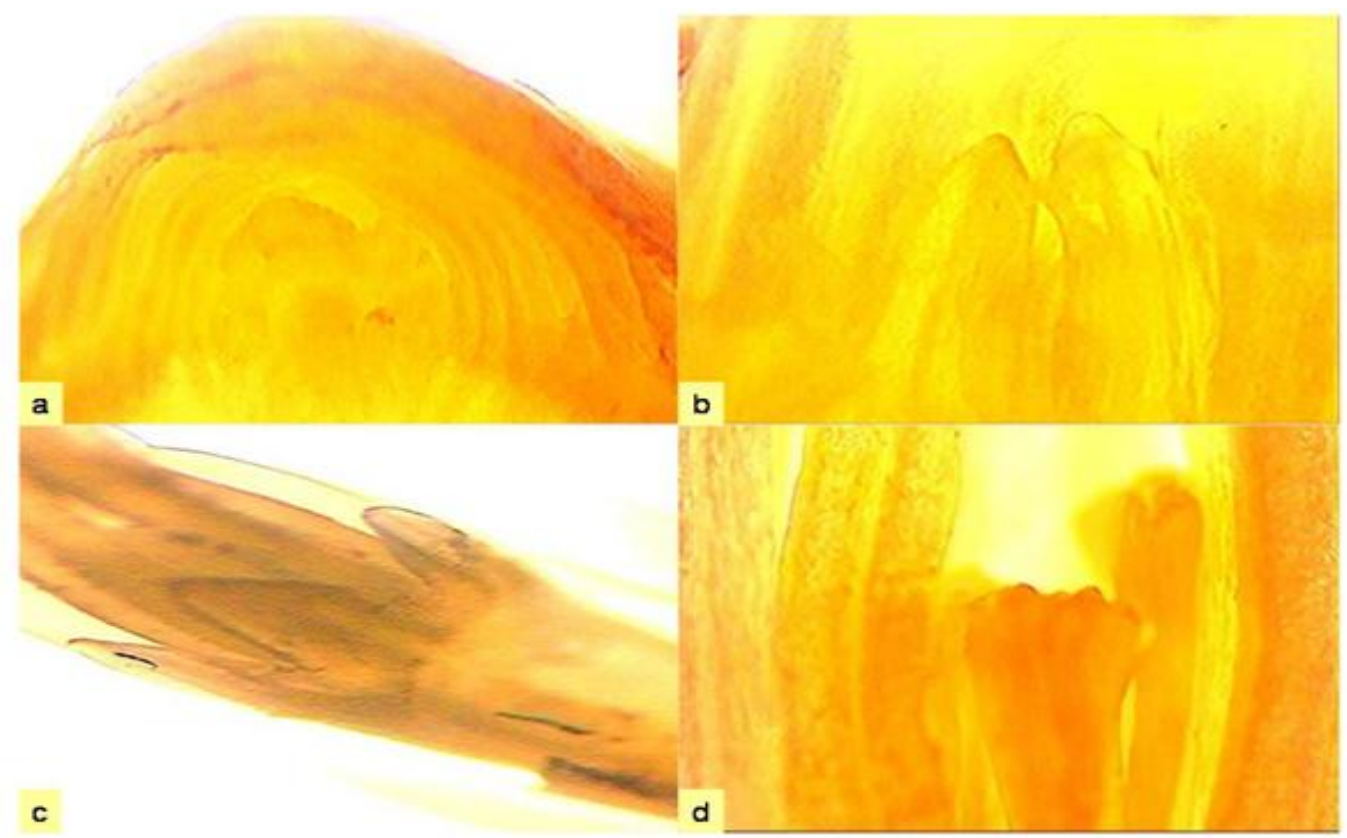

Figure 3

Fig.4 Bud Sprouting (BS). a,) Sprout Initiation and fibrous root development.(BS). b,) Sprout length reaches to $4 \mathrm{~cm}$ length (BS.1). c) Sprout length reaches to $12 \mathrm{~cm}$ (BS.2).d, g) Longitudinal section showing floral initials in vascular bundle (BS). e, h) Longitudinal section showing floral parts in the sprout.(BS.1).f,i) Sprout length reaches to $13 \mathrm{~cm}$ and Longitudinal section showing complete floral parts embedded in whorl of tepals (BS.3)

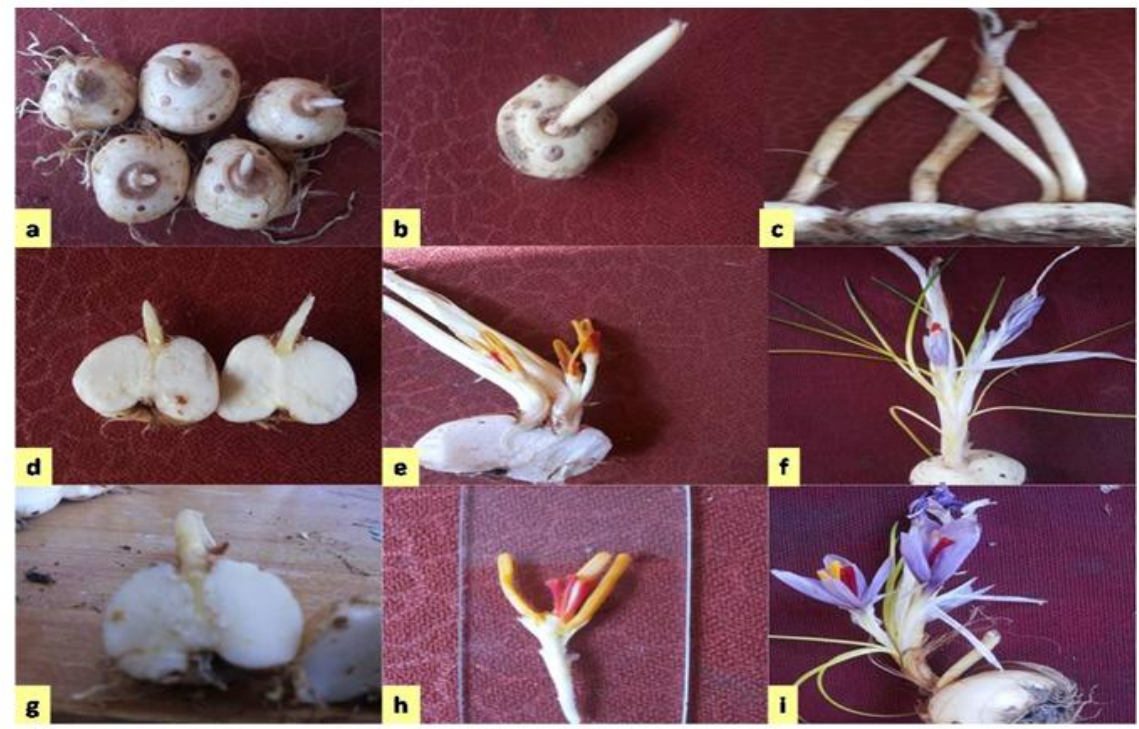

Figure 4 
Fig.5 Impact of corm weight on sprout length over different periods of sprouting

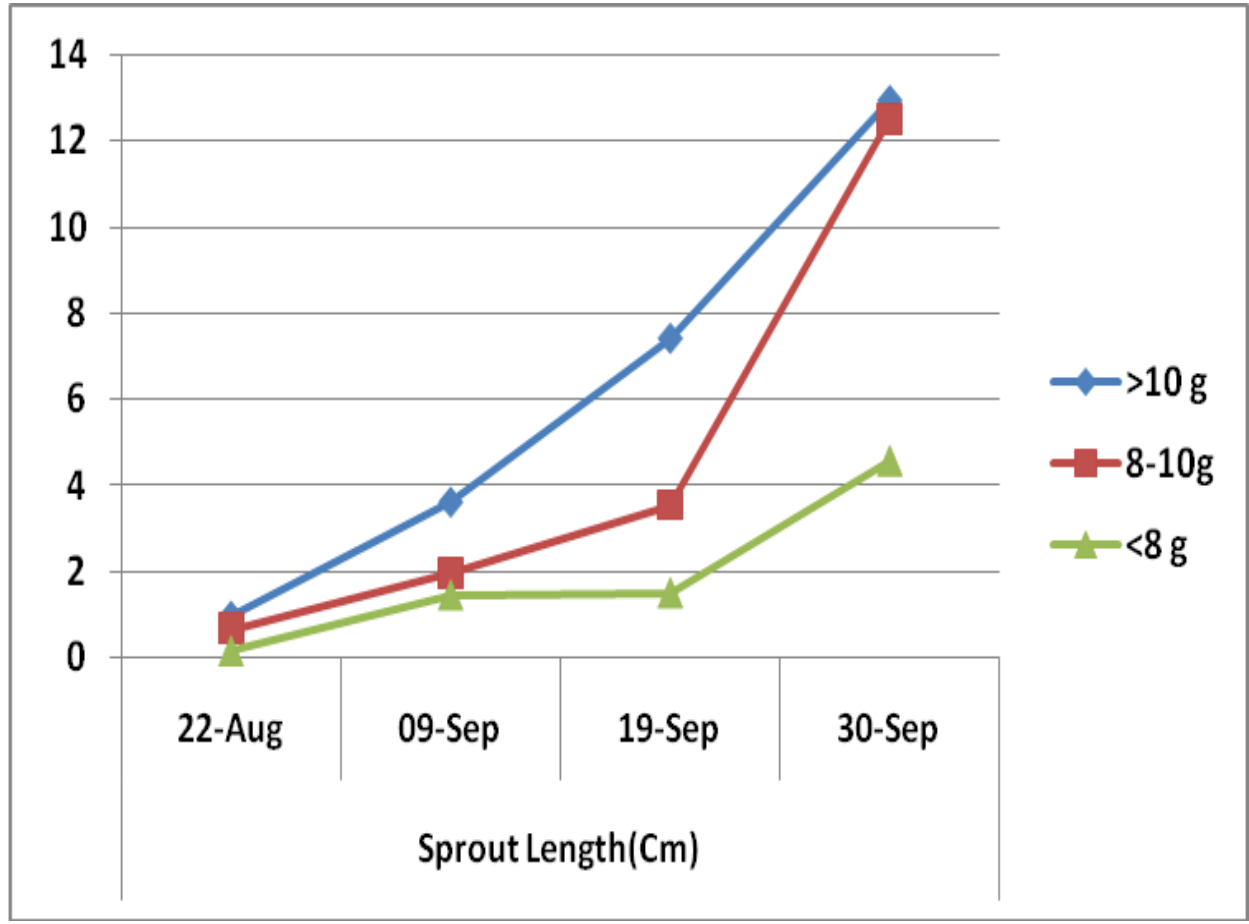

Figure 5

Fig.6 Impact of corm weight on number of flowers/sprout and sprout width

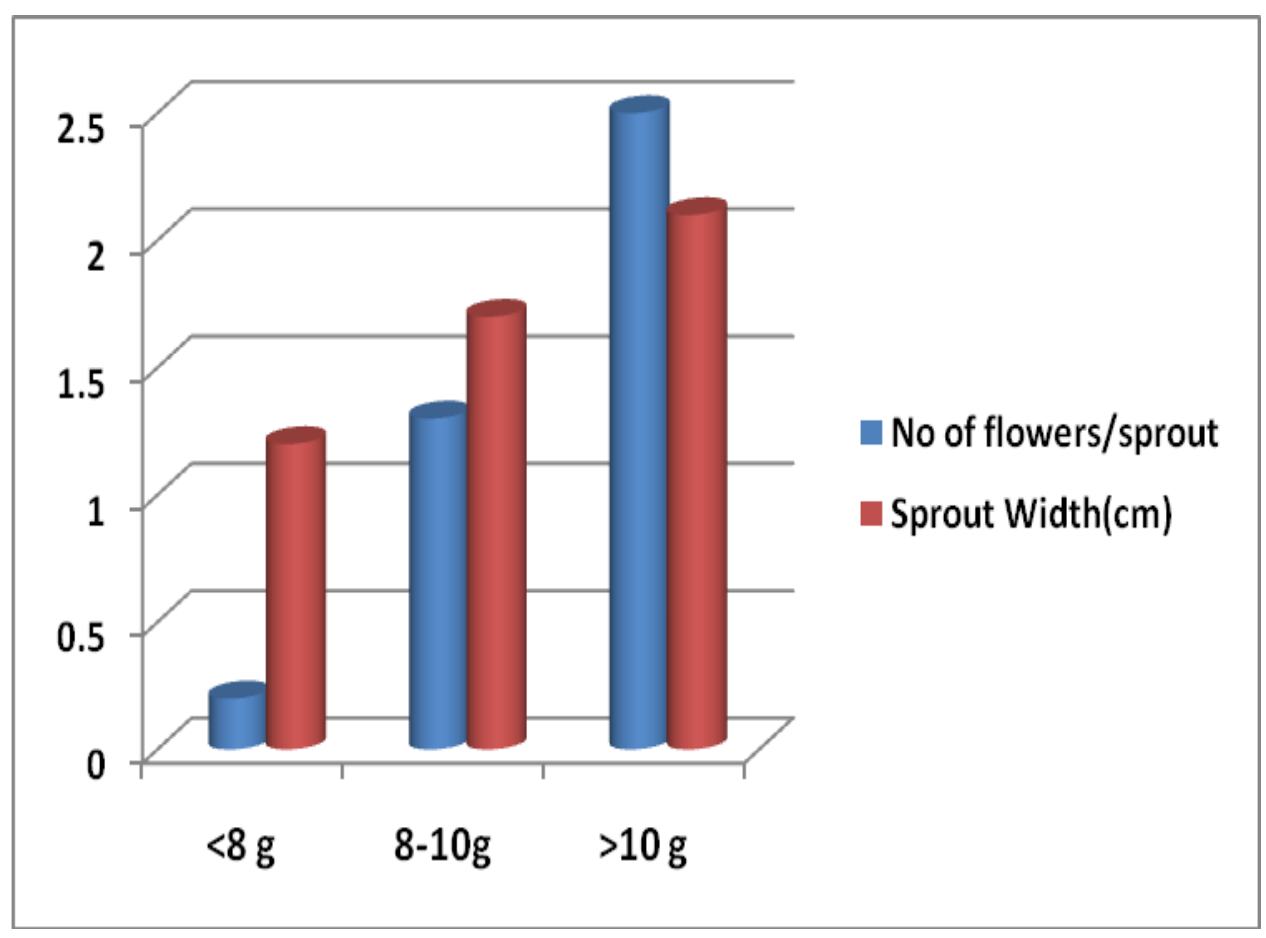

Figure 6 
Fig.7 Effect of corm weight on number of flowers/sprout and sprout width (cm) a) $>10 \mathrm{~g}$ Corm weight showing profuse activation from apical and axiullary buds. b) $8-10 \mathrm{~g}$ corms showing activation from apicular region) $<8 \mathrm{~g}$ corm showing slow sprout growth. $\mathrm{d}$ ) $>10 \mathrm{~g}$ corms showing 3 flowers/ spathe with $2.7 \mathrm{~cm}$ sprout width. e) $8-10 \mathrm{~g}$ corm showing 1 flower/spathe with $2.1 \mathrm{~cm}$ sprout width $\mathrm{f}),<8 \mathrm{~g}$ corm showing no flowers/spathe with $1.2 \mathrm{~cm}$ sprout width

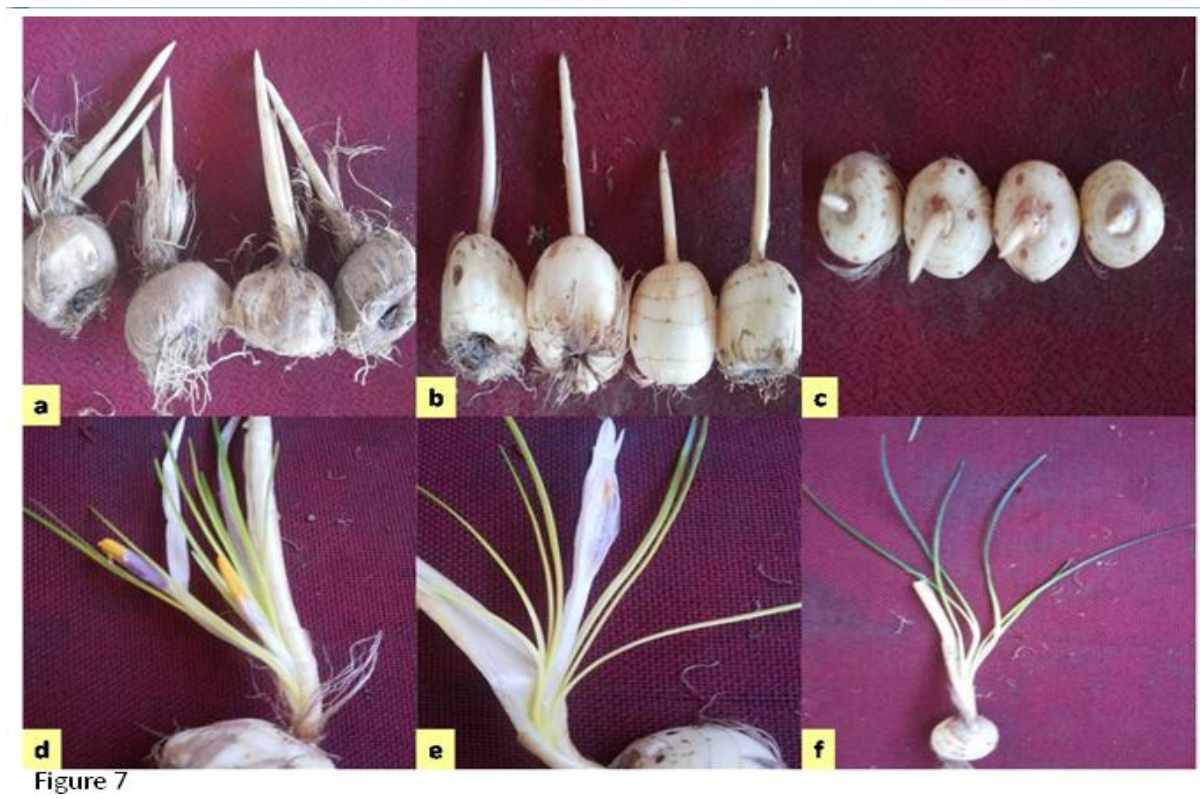

Fig.8 Reproductive Phase(R).a) Flowering: Shoots (cataphylls) breaking through soil surface. Flower cataphylls are visible above ground, enveloped by its bracts. Flower cataphylls still closed (R.1). b) blooming (unopened flowers with floral organs enclosed by the tepals. (R.2), c), anthesis (opened teplas with visible stigma and anthers. (R.3), d,) flower senescence. Tepals dehydrate and falls on the ground (R4)

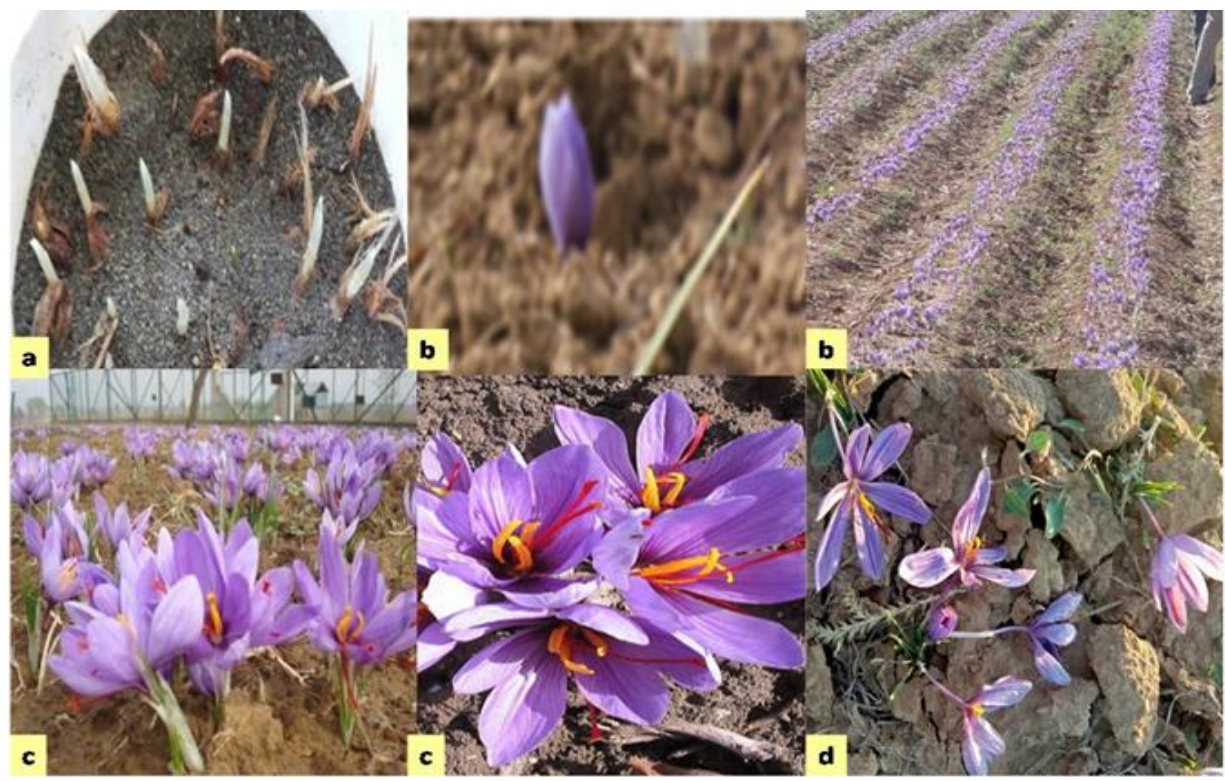

Figure 8 
Fig.9 Vegetative phase. (VE). a) Leaves from the lateral bud region are first visible above ground (VE.1). b) Leaves growth at 80\% of final length, (VE.1.1), c), Development of corm, lateral bud and terminal bud contractile roots (VE.2), d) Formation of replacement corms. (VE.3). e) Leaves grow at $100 \%$ of final length (VE.3.1). f) Leaf and corm Development completed (VE.4)

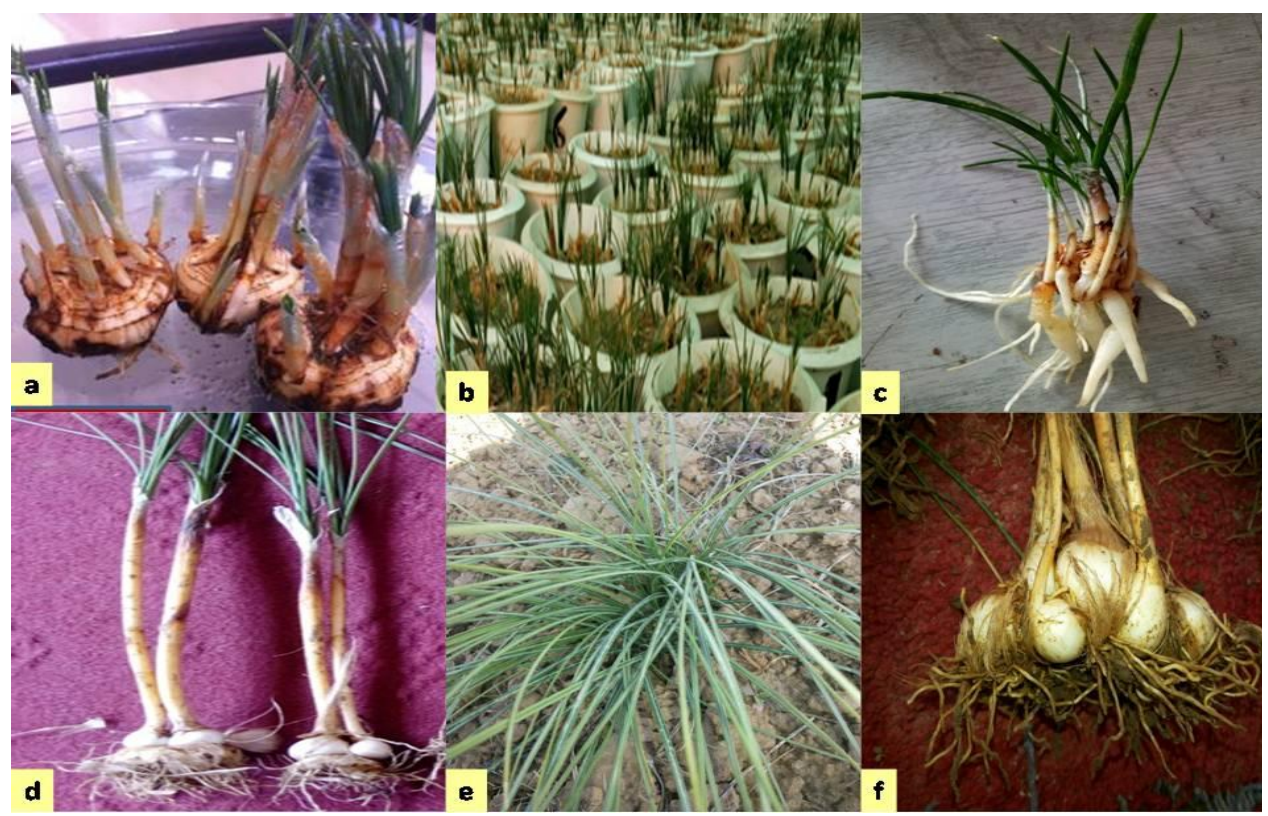

Figure 9

Fig.10 Effect of corm weight on number of leaves

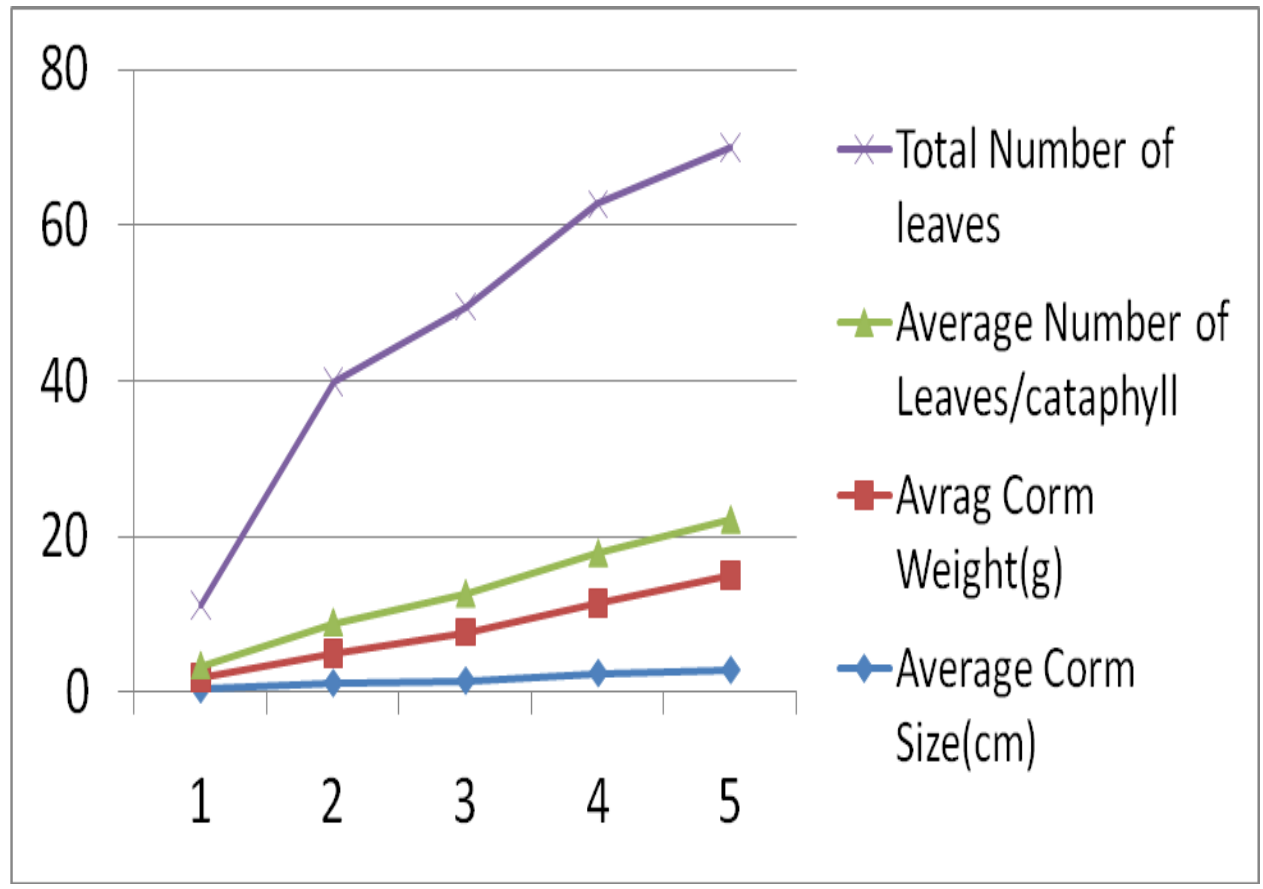

Figure 10 
Fig.11 Periodical incremnt in leaf length duribng vegetative phase

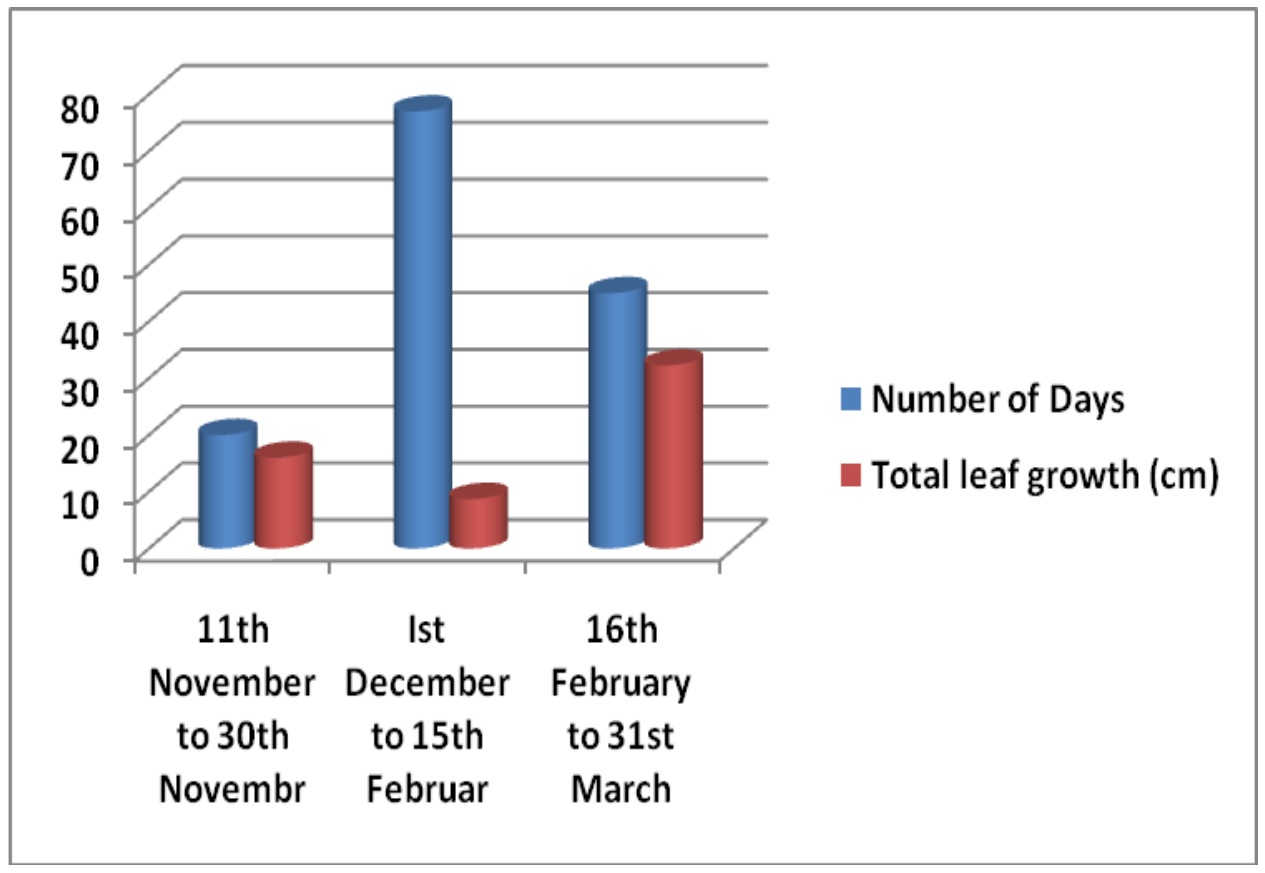

Figure 11

Fig.12 Plant senescence (R). a) Leaves show signs of prominent senescence (VE.5). b) Development of fully mature daughter corms (VE.5.1)

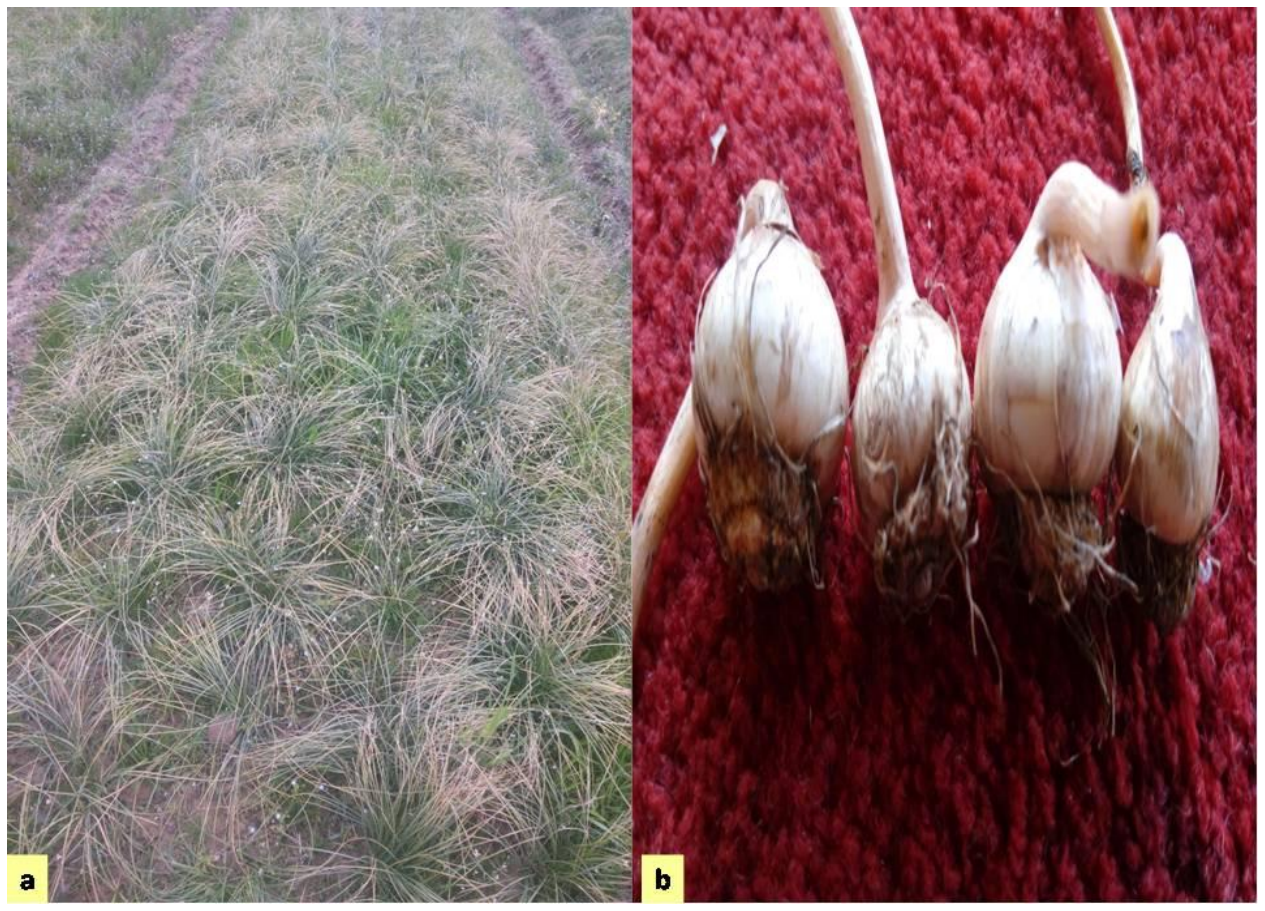

Figure 12 
About 1,30000 flowers which weigh over $42.38 \mathrm{~kg}$ are required in Kashmir to obtain 1 $\mathrm{kg}$ of saffron spice taking into account that stigmas lose $75 \%$ of their fresh weight during dehydration process followed traditionally in Kashmir. Hence about $39.04 \mathrm{~kg}$ of bioresidues are generated in the production of $1 \mathrm{~kg}$ of saffron spice.

\section{Vegetative}

Vegetative phase is the most important and critical stage of plant phenology as during this the plant receives 1100 chilling hours that is requisite for vernalization. During vegetative phase the crop receives an average maximum temperature of $11.4^{\circ} \mathrm{C}$, average minimum temperature of $-0.33^{\circ} \mathrm{C}$, morning relative humidity of $88.6 \%$, average evening relative humidity of $60.4 \%$ and precipitation of $474 \mathrm{~mm}$ (Figure 1and Table 2). Chilling requirement for vernalization is received during 66 days $\left(11^{\text {th }}\right.$ November to $15^{\text {th }}$ February) observing an average minimum temperature of $-2^{\circ} \mathrm{C}$ associated with a maximum air temperature of $9.8^{\circ} \mathrm{C}$.

Vegetative phase starts when the shoot (usually composed of three sheaths) emerges from the soil surface. Vegetative developmental stages are designated as $\mathrm{V}$ stages, beginning at VE (emergence of the sheaths above the ground) and extend until the last leaf is visible (Figure 9). Vegetative phase lasts for 142 days $\left(11^{\text {th }}\right.$ November to $30^{\text {th }}$ March) (Figure 1). There are four stages within the vegetative phase: Flower score VE.1 (Figure 9a), flower score VE.1.1 (Figure 9b), flower score VE.2 (Figure 9c), flower score VE.3 (Figure 9d) Flower score VE.4 (Figure 9e) and flower score VE.5 (Figure 9f). Foliar structures begin to appear from 3-5 tubular tunics of white colour known as cataphylls. Cataphylls protect and strengthen stems in the process of appearance on the surface and protect the corms once formed from dehydration and possible lesion. 5-11 green leaves or monophylls between 1.5 and $2.5 \mathrm{~mm}$ wide are found per sprout and are called bristles and can measure up to $50 \mathrm{~cm}$. In saffron, leaves can be synanthous or hysteranthous at flowering time. However if the irrigation is started early leaf appear before flowering transferring the hysteranthous behaviour of saffron into synanthous behaviour. The number of leaves are positively correlated with the size of the corm. The number of leaves is also influenced by the position of the bud on the planted corm (Figure 10). The base of the leaf is expanded forming the upper cap corm tunic. The blades are linear lanceolate. Study revealed that corms weighing $12.2 \mathrm{~g}$ with a corm size of $2.9 \mathrm{~cm}$ recorded maximum number of leaves (48)/plant and maximum number of leaves per cataphyll (7). Similar effect of corm weight for incremental increase in number of leaves was recorded by corms weighing $8.9 \mathrm{~g}$, $6.2 \mathrm{~g}, 3.8 \mathrm{~g}$ and $1.4 \mathrm{~g}$ revealing $45,37,31$ and 7.8 number of leaves/plant, respectively (Figure 4). Maximum leaf growth $(32.25 \mathrm{~cm})$ is observed during $16^{\text {th }}$ February to $30^{\text {th }}$ March (45 days) at an average growth of $0.75 \mathrm{~cm} /$ day followed by $16 \mathrm{~cm}$ achieved @ $0.80 \mathrm{~cm} /$ day in 20 days (11th November to 30th November). However least growth $(8.74 \mathrm{~cm})$ is observed in 77 days $\left(1^{\mathrm{st}}\right.$ Decmber to $15^{\text {th }}$ February) observing low temperatures (Figure 11).

During 45 days ( $1^{\text {st }}$ January to $15^{\text {th }}$ February) corm, lateral bud and terminal bud contractile roots are developed, whereas fibrous contractile roots are developed prior to flowering. In every corm 8-14 fibrous contractile roots are formed. Corm contractile roots are produced from fibrous root rings, but rather originate from the peripheri. About 1-2 contractile roots are produced in every corm, Lateral bud contractile roots originate from the base of lateral buds and continue to grow and become contracted during the 
Senescene. About 3-5 lateral bud contractile roots are developed. Terminal bud contractile roots appear in the base of apical bud. First they are seen as small tuberous root and are thicker than the other types. Their number generally varies from 2-3/corm. Corm depth is an important factor for development of contractile roots.

Maryam et al., (2004) also reported similar results. Formation of replacement corms (Recaptuation stage) is another most important stage of vegetative phase. Stage is economically important because formation of replacement corms contribute to important corm attributes viz., multiplication ratio, big corm index and flower raising index. Study revealed that replacement corms (daughter corms) initiate from apical and axillar buds from January followed by development of replacement corm from lateral buds depending upon the initial corm weight. Faster development of replacement corms depends on better source (leaves) and sink (replacement corms) relationship. Better relationship improves big corm index (proportion of bigger corms to the total number of developed corms). Escribano et al., (2000) also reported importance of better source sink relationship

\section{Plant senescence}

Plant senescence becomes prominent from $\mathrm{I}^{\text {st }}$ week of April when leaves show signs of prominent senescence (Flower Score VE.5; Figure 12a). After 30 days of downward translocation of photosynthates from source into sink fully mature daughter corms are developed with reduced impression of mother corms (Flower Score VE.5.1; Figure 12b). Plant senescence is completed under maximum temperature of $19.3^{\circ} \mathrm{C}$, minimum temperature of $6.2^{\circ} \mathrm{C}$ accompanied with morning and evening relative humidity of $84.7 \%$ and $63.5 \%$, respectively (Figure 1).
Stage is sensitive to corm rot because plant receives about $219.15 \mathrm{~mm}$ rainfall during this phase.

\section{Acknowledgement}

Authors thankfully acknowledge the financial support provided by Ministry of Agriculture Govt of India under National Saffron Mission Project

\section{References}

Botella O, de Juan JA, Muñoz MR, Moya A, López-Córcoles H, 2002. Descripción morfológica y ciclo anual del aza-frán (Crocus sativus L.). Cuadernos de Fitopatología 71: 18-28.

Carmona M, Zalacaín A, Alonso G, 2006. El color, sabor yaroma del azafrán especia. Altaban Ediciones, Albacete, Spain

Chrungoo N, Koul KK, Farooq S, 1983. Carbohydrate changes in corms of saffron crocus (Crocus sativus L.) during dormancy and sprouting. Trop Plant Sci Res 1 (4): 295-298

De Mastro, G. and Rute, C. 1993. Relative between corm size and saffron (Crocus sativus L.) flowering. Acta Horticulturae 344: 512-517.

Dhar, A. K. and Mir, G. M. 1997. Saffron in Kashmir VI. A review of distribution and production. Journal of Herbs, Spices and Medicinal Plants 4: 83-90.

F.A.Nehvi.2011. Good Practices for Saffron Cultivation in Kashmir " A Practical Manual. SKUAST-K Publication

Fehr W.R., Caviness C.E. 1977. Stages of Soybean Development. Ames, IA, USA: Iowa State University of Science and Technology (Special Report, 80).

Garcia-Carbonell S., Yagüe B., Bleiholder H., Meier U., Augusti M. 2002. Phenological growth stages of the persimmon tree (Diospyroskaki). Annals of Applied Biology, 141, 73-76. 
Hanway J.J. 1966. Growth stages of corn (Zea mays L.). Agronomy Journal, 55, 487492.

Hodges T. 1991. Introduction. In Predicting Crop Phenology, pp. 1-2. Ed T. Hodges. Boston, MA, USA: CRC Press.

Horacio Lopez-Corcolesm, Antonio BrasaRamos, Francisco Montero-García, Miguel Romero-Valverde and Francisco Montero-Riquelme.2015.Phenological Growth stages of saffron Plant (Crocus sativus L.) according to the $\mathrm{BBCH}$ Scale. Spanish journal of Agricultural Research 13(3):e09sc01

Koul, K. K. and Farooq.S.1984.Growth and differentiation in the shoot apical meristem of the saffron plant (Crocus sativus L) Indian. Bot.Soc.63: 153-160

Large E.C. 1954. Growth stages in cereal illustration of the Feekes scale. Plant Pathology, 3, 128-129.

Le Nard M, De Hertogh AA, 1993. Bulb growth and development. In: The physiology of flower bulbs; De Hertogh A and Le Nard M (eds), pp: 29-43. Elsevier Science Pub, Amsterdam, The Netherlands.

Meier U, Bleiholder H, Buhr L, Feller C, Hack H, Hess M, Lancashire PD, Schnock U, Stauss R, van den Boom T, Weber E, Zwerger P, 2009. The BBCH system to coding the phenological growth stages of plants - His-tory and publications. Journal Für Kulturpflanzen,z 61:41-52

Meier U., Bleiholder H., Buhr L., Feller C., Hack H., Heß H., Lancashire P.D., Schnock U., Stauß R., Van Den Boom T., Weber E., Zwerger P. 2009a. The $\mathrm{BBCH}$ system to coding the phenological growth stages of plants history and publications. Journal für Kulturpflanzen, 61, 41-52.

Molina RV, Valero M, Navarro Y, Guardiola JL, Garcia-Luis A, 2005. Temperature effects on flower formation in saffron
(Crocus sativus L.). Scientia Hort 103: 361-379.

Negbi, M. Saffron cultivation: Past, present and future prospects.P.,1-17.In: M. Negbi (ed) Saffron (Crocus sativus L) Harwood, Amesterdam 1999

Negbi, M., Dagan, B., Dror, A. and Basker, D. 1989. Growth, flowering, vegetative reproduction and dormancy in the saffron crocus (Crocus sativus L.). Israel Journal of Botany 38: 95-113.

Nehvi, F.A., Salwee Yasmin, Sabeena Naseer, Shaheena Nagoo, Niyaz Ahmad and Bashir Ahmad Elai. 2017. Good practices for saffron production under high density plantation in Jammu and Kashmir. Published by Sher-e-Kashmir University of Agricultural Sciences and Technology of Kashmir

Pérez Bueno M, 1988. El azafrán: cultivoenfermedades rendimientosindustrialización. Mundi Prensa Libros. Madrid, Spain. 155 pp.

Plessner O, Negbi M, Ziv M, Basbe D, 1989. Effects of temperature on the flowering of the saffron crocus (Crocus sativus L.): induction of hysteranthy. Isr $\mathbf{J}$ Bot 38: $1-7$.

Poggi LM, 2009. Problemáticas y nuevas perspectivas tecnológicas para la producción de azafrán. Horticultura Argentina 28: 39-6

Ritchie S.W., Hanway J.J., Benson G.O. 1993. How a Corn Plant Develops. Ames, IA, USA: Iowa State University of Science and Technology, Cooperative Extension Service (Special Report, 48)

Rosa V. Molina, Amparo Garcia-Luis, Virginia Coll, Clra Ferrer, Miguel Valero, Yolnda Navarro and Jose L. Guardiola. 2004. Flower formation in the saffron crocus (Crocus sativus L). The role of temperature. Acta Horticulturae 650:39-47 
Salwee Yasmin, F. A. Nehvi, J. K. Dhar, Sabina Naseer, Shaheena Nagoo, Gowhar Ali and Asif A. Qureshi. 2017. Saffron Improvement improvised methods. In: Quality and Quantum Improvement in field crops. Edited by C. P. Malik, Shabir Hussain Wani, Himakshi Bhati-Khuswaha and Ritsh Kaur. Publisher: Agrobios (India) Publication.PVT Ltd Jodhpur.PP225264

Salwee Yasmin, F.A. Nehvi and Shafiq A Wani.2012. Saffron-The Goden Condiment A Review of $\mathrm{R}$ and $\mathrm{D}$ Interventions. SKUAST-K Publication

Sánz-Cortés F., Martínez-Calvo J., Badenes M.L., Bleiholder H., Hack H., Llácer G., Meier U. 2002. Phenological growth stages of olives trees (Olea europaea). Annals of Applied Biology, 140, 151157Sánz-Cortés F., Martínez-Calvo J., Badenes M.L., Bleiholder H., Hack H., Llácer G., Meier U. 2002. Phenological growth stages of olives trees (Olea europaea). Annals of Applied Biology, 140, 151-157.

Schwab, N.T., Streck, N.A., Becker, C.C., Langner, J.A., Uhlmann, L.O and M.R. Ribeiro M B.S. 2015. Phenological scale for the development of Gladiolus. Ann Appl B iol 166: 496-507

Streck N.A., Weiss A., Xue Q., Baezinger P.S. 2003 Incorporating a chronology response function into the prediction of leaf appearance rate in winter wheat. Annals of Botany, 92, 181-190.

Vela P, Salinero C, Sainz MJ, 2013. Phenological growth stages of Camellia japonica. Ann Appl Biol 162: 182-190

Wareing PF, Phillips IDJ, 1981. Growth and differentiation in plants. Pergamon Press, $343 \mathrm{pp}$

Zadoks JC, Chang TT, Konzak CF, 1974. A decimal code for growth stages of cereals. Weed Res 14: 415-421

\section{How to cite this article:}

Salwee Yasmin and Nehvi, F.A. 2018. Phenological Growth Stages of Saffron (Crocus sativus L.) under Temperate Conditions of Jammu and Kashmir-India. Int.J.Curr.Microbiol.App.Sci. 7(04): 3797-3814. doi: https://doi.org/10.20546/ijcmas.2018.704.428 